\title{
REVIEW OF THE ELEMENTS INFLUENCING JOB SATISFACTION ON JOB PERFORMANCE, WITH QUALITY OF WORK LIFE AS MEDIATING IN THE JORDANIAN HOTEL INDUSTRY
}

\author{
Bandar Ersan Alown ${ }^{1}$, Mahadzirah Binti Mohamad ${ }^{2}$, Fazida Karim ${ }^{3}$ \\ 1 Faculty of Economic, Universiti Sultan Zainal Abadin (UNISZA), Malaysia. \\ Email: bandaraloun@gmail.com \\ 2 Faculty of Economic, Universiti Sultan Zainal Abadin (UNISZA), Malaysia. \\ Email: mahadzirahmd@unisza.edu.my \\ 3 Faculty of Economic, Universiti Sultan Zainal Abadin (UNISZA), Malaysia. \\ Email: fazidakarim@unisza.edu.my
}

\section{Article Info:}

\section{Article history:}

Received date:23.01.2020

Revised date: 03.02.2020

Accepted date: 04.02.2020

Published date: 13.03.2020

\section{To cite this document:}

Alown, B. E., Mohamad, M., \& Karim, F. (2020). Review of The Elements Influencing Job Satisfaction on Job Performance, with Quality of Work Life as Mediating in The Jordanian Hotel Industry. Journal of Tourism, Hospitality and Environment Management, 5 (18), 25-40.

DOI: 10.35631/JTHEM.518003.

\begin{abstract}
:
The hotel industry is a major pillar of tourism because of the services it provides in the field of the national economy, as a result of the funds it pumps, and as a means of obtaining the foreign currency necessary to implement the comprehensive development plans in the countries of the world. This paper aims to examine the factors influencing the job performance of the Jordanian hotel industry. This study relied on the theoretical approach by reviewing the theoretical literature and previous studies related to the variables of the study. A survey of previous studies and theories related to the subject of the study was conducted. Many factors have been disregarded in numerous writing in light of job satisfaction and job performance, and in view of the survey discoveries; there is a positive connection between organisation structure, leadership style, job satisfaction, quality of work-life, and job performance. The present paper proposed to the hotel industry to the firm-up interconnection between job satisfaction, quality of work-life, and job performance. It similarly enumerated equally theoretical and practical ramifications based on earlier writing and suggested future studies to concentrate more on the factors affecting job performance in Jordanian hotels.
\end{abstract}

Keywords:

Jordan, Hotel Industry, Job satisfaction, Job Performance 


\section{Introduction}

In today's competitive world, the key to success in any business, such as the hotel industry, relies on the employees who are the assets of any organisation and who play a crucial role in driving the profit of an organisation. Thus, organisations have to be concerned about their employees' job satisfaction and quality of work life. Based on the Theory of Service Chain Profit (Heskett \& Schlesinger, 1994), employee satisfaction plays an important role in generating profit in the service industry. When employees feel satisfied and happy in their work, they are happy to deal with customers and meet their expectations. Thus, job satisfaction is important in the hotel industry.

Tran and Tian (2013) defined organisational structure as "the allocation of work roles and administrative mechanisms to control work activities and the hierarchical relations among members of the organisation." In addition, leadership style includes a process of influencing by the leader in governing the behaviour of subordinates towards attaining the goals of the organisation (Zheng et al., 2010). Considering all these factors, this current study investigated the impact of organisational structure and leadership style on the satisfaction of jobs.

Employee satisfaction is a crucial factor for the hotel industry because it is invariably related to the employees that are responsible for the service delivery and thus, they are the crucial link in the value chain. The hotel industry being a service oriented industry involves people dealing with people and in this context, a satisfied will provide good service to the hotel guests and ensure their satisfaction with the level of service they receive (Campbell et al., 1993). Also, employees in the hotel industry are the key personnel who contribute to giving guests the satisfactory experience they expect. In the marketing context there is nothing better than a satisfied client and in the case of the hotel industry it will translate into repeat patronage which would contribute to enhancing organisational performance. Several studies have determined that quality of work life influences job performance (Hosmani \& Shambhushankar, 2014; Rai \& Tripathi, 2015; Chanana \& Gupta, 2016). For example, Chanana and Gupta , (2016) also indicated the high impact that quality of work life has on employee work outcomes. In light of these findings it is recommended that there be further study of the relationship between quality of work life and work performance among employees in the Jordanian hotel industry. Besides that, Hamideh et al. (2015) indicated that centralised organisational structure which provided authority to employees to design jobs might meet the expectations of employees, and increase their quality of work life. These studies indicated that an organisation should design a suitable structure that can increase the quality of work life especially in the hotel industry. This is because hospitality organisations are complex entities which need to coordinate a number of services that make up the task environment that must be properly organized (Øgaard et al., 2008).

The hospitality industry is diverse and encompasses activities ranging from exclusively catering to catering as well as accommodation, sole trader catering to the government and who received subsidies and whose activities are government-controlled; single hotel operations to chain operators, and eating for pleasure, to eating to survive, The hotel industry is therefore complex and heterogeneous (Øgaard et al., 2008) with its core offerings being accommodation, food and beverage. Employees are entrusted to carry out their roles according to the standard set via the organisation.

This study primarily attempts to determine the antecedent and consequences of job satisfaction and their influence on job performance in the Jordanian hotel industry. 


\section{Literature Review}

Hospitality industry has been growing around the world and it also as a major force in the Jordanian economy. According to Council, (2017), the total contribution of Travel \& Tourism to GDP was USD7, 640.7 million, $19.4 \%$ of GDP in 2016. The great contribution of travel and tourism advances the overall economy in Jordan especially in employment. However, tourism industry especially hotel industry is facing problem of shortage manpower (Timothy, 2017). In hotel industry, Chiang et al., (2014) mentioned that employees are experience the greatest satisfaction when their jobs offer them reward, training and good organisational structure. Based on Grant and Parker (2009), social support such as organisation and supervisor support is one of the expected influential factors that impact satisfaction of job. Therefore, if employees perceive that these expectations are met, it will improve employee satisfaction level and have an optimistic influence on the performance of jobs. Moreover, Damayanthi et al. (2014) pointed to the close relationship between the way an organisation is structured and manager's leadership style and the level of employee's satisfaction with his/her job.

Employee satisfaction has a massive impact on organisational outcomes by means of employee income, business performance, work life balance and organisational commitment (Al-Refaie, 2015, Lee \& Grover, 1999, Pan, 2015, Liu et al., 2010). It suggests that when employees have high job satisfaction, they remain with the organisation and are likely to provide better performance in the organisation. Employee satisfaction is a crucial factor for the hotel industry because it is invariably related to the employees that are responsible for the service delivery and thus, they are the crucial link in the value chain.

Job satisfaction is a widely accepted predictor of productivity (Robbins, 2009). Employees are the crucial asset of any organisation especially in building its competitive advantage. According to service profit chain theory, employee satisfaction can improve quality of service which results in high customer satisfaction and able to make the organisation profitable. Based on previous research, organisational structure is one of the reasons for employee satisfaction (Thomas, 2015; Picardi, 2017).

The hotel industry being a service-oriented industry involves people dealing with people and in this context, a satisfied will provide good service to the hotel guests and ensure their satisfaction with the level of service they receive (Campbell et al., 1993). Based on previous studies, job satisfaction is also an indicator for quality of work life across different industries (Owolabi, 2015; Babu \& Ramesh, 2013; Chen et al., 2015). Recent findings have reinforced the belief that job satisfaction affects employee's quality of work life (Bhavani \& Jegadeeshwaran, 2014). For example, Owolabi (2015) maintained that if employees perceive that their job satisfaction is being looked after, it will help improve their perception of quality of work life. Besides that, a review study conducted by Sinha (2012) concluded the satisfaction of job and work life quality is connected. Recognising this will help in defining the satisfaction level of employee or commitment and enthusiasm about his/her job. In practical terms, the satisfied worker is likely to willingly participate and thus improve his/her quality of work life.

Quality of work life refers to an idea that includes the employee's well-being at the workplace. There are several definitions of quality of work life. Boisvert, (1977) defined it as "a set of beneficial consequences of work life in the workplace, which includes other life domains (e.g., family, leisure, and social domains)." In any case, Carayon (1997) indicated major variables of quality of work life, namely environment, tools, organisational factors, individual task, and technology, and provided assessments of the complexity of interrelationships. 
The quality of work life in general takes an association with a number of objective organisational conditions and practices that allow employees to perceive that they have security are satisfied and have the opportunity to grow and develop as individuals. Without a good organisational structure, employees will perceive their quality of work life is low. Srivastava (2016) defined organisation structure as "the arrangement of task, interrelations of various departments and levels of authority to achieve co-operation of efforts, delegation of authority and effective communication along the scalar chain of command. "Examples would include: formality, option, hierarchy, and centralization, which are organisational structure components that influence the enhancement of work life quality (Salimbahrami et al., 2015).

Also, job performance plays important role in sustaining the business especially in hospitality organisations. This is because hospitality organisation requires employees to coordinate multiple services in order to provide a task environment that has to be well organized. Moreover, Hospitality organisations are a complex and heterogeneous organisation because it requires coordinating multiple services in order to provide a task environment that has to be well organised. Besides this, employees have to ready to solve different type of ad hoc problem in a continuously changing environment. For hotel to survive commercially, they have to implement a good strategic plan to deal with the rapid change of technology and competitive industry. There is study stated that less than thirty percentage of organisations in the service industry successfully implement strategic planning (Nabwire, 2014). This failure was caused by organisational factors such as leadership styles and organisational structure (Sekaran \& Bougie, 2010).

Additionally, the performance of employees is greatly reliant on the quality of work life. Thus, business organisations with good quality of work life will have employees demonstrating good performance (Chanana \& Gupta, 2016). However, the literature is showing very limited investigation and explanation of the relationship between quality of work life and job performance. Therefore, by examining the effects of quality of work life on job performance among hotels operating in Jordan, this study will hopefully fill the aforesaid gap.

Hence, it is hypothesised that:

H1a: Organisation structure has a significant influence employees' job satisfaction in the Jordanian hotels sector.

H1b: Leadership style has a significant influence on employees' job satisfaction in the Jordanian hotels sector.

H2: employees' job satisfaction has a significant influence on their job performance in the Jordanian hotels sector.

H3: Employees' job satisfaction has a significant influence on their quality of work life.

H4: Employees' quality of work life has a significant influence on their job performance

H5: quality of work life mediates the relationship between job satisfaction and job performance.

\section{Underpinning Theories}

\section{Transformational Leadership Theory}

Transformational leadership theory is among the noteworthy theories underpinning leadership in the 21st century (Barbuto, 2005; Bass \& Riggio, 2006; Brymer \& Gray, 2006). As mentioned by Northouse, (2017), transformational leaders revolve around the subordinates particularly in terms of their personal and development needs. Within the competitive environment, transformational leaders motivate and help the subordinates succeed by influencing them to 
show performance that supersedes expectations. Also, as mentioned by Bass and Riggio (2006), transformational leaders inspire the subordinates to prioritise the organisational interest.

The theory of transformational leadership able to shape the current study's theoretical ground seeing that this theory matches this study's objectives, with consideration on the direct and significant connection between leadership styles and job satisfaction and quality of work life, the determinants deemed important for job performance (Eliyana \& Ma'arif, 2019)

\section{Social Exchange Theory}

A major view of the Theory of Social Exchange (SET) indicates that relationships take time to evolve into trusting, loyal, and mutual commitments (Xerri, 2013). On the other hand, the successful development of workplace social network ties come about over time, SET suggests that such relationships begin and are fostered under ideal conditions (Cole et al., 2002). Job satisfaction is focused mainly on subjective response to the experience of their job. This is likely the most commonly examined job attitude. In the literature, the definition of job satisfaction could be: "a positive emotional state resulting from employees' appraisal of their jobs" (Taylor, 2007). As reported by social scientists, job satisfaction is the outcome focuses on employees' responses to their job experiences (Mowday et al., 2013).

In the hotel setting, frontline employees may have social exchanges with three groups of people, including leaders, co-workers and customers which gave active and passive participation of these parties. The social-engage theory able to shape the current study's theoretical ground seeing that this theory matches this study's objectives, with consideration on the direct and significant connection between job satisfaction and job performance (Yalabik, Rayton \& Rapti, 2017).

\section{Resource-Based View}

The resource-based view is an area that is rising and dominant in the literature of strategy which tackles the question of the identity of an organisation. RBV mainly revolves around the source and nature of strategic capabilities. As mentioned by Barney, (1991) and Wernerfelt, (1984), RBV comprises intra-organisational focus. The author added that performance is an outcome of resources and capabilities specific to the firm. RBV posits that effective firms will discover their forth coming competitiveness on the creation of unique capabilities, which may every so often be implicit or intangible (Teece et al., 1997). Hence, the strategy essences or should be illustrated by the unique resources and capabilities that firms have (Rumelt \& Lamb, 1997). Additionally, the strategy's value-creating potential comprises the capacity that firm has in the establishment and preservation of a profitable market position and such potential is highly dictated by the rent-generating capacity of the underpinning resources and capabilities that firm possesses (Barney et al., 2011). Firms that are equal in resources will have identical profitability. This owes to the fact that in a similar industry, any strategy is implementable by any firm (Barney, 1991). It should be noted that effects' sustainability of a competitive position primarily relies on the cost of resources and the employed capacities in the implementation of the pursued strategy. Barney, (1986) mentioned that this cost is analysable pertaining to strategic factor markets which entail the markets of which the necessitated resources are obtained. That strategic factor markets have been argued to be faultily competitive owing to differing expectations, information asymmetries and even luck with respect to the future value of strategic resources. 
To date RBV was linked with employee performance at human resource level in the tourism and hospitality industry (Hofmann \& Stokburger-Sauer, 2017). Studies relating RBV with job satisfaction and job performance are limited across the sectors. RBV can be linked with organizational structure with resources and capabilities that are unique to the organization which is linked to the job performance of employees and enhance the competitive advantage and performance outcomes. Although this strategy has its own cost impact; however, such type of resources and capabilities can be crucial factors of sustainable competitive advantage and superior organization performance providing that the organizations do have some one-of-akind characteristics. This will in directly sustain the loyalty of the employees via the high job satisfaction, high motivation and feel being appreciated in the organization and provide positive outcomes in term of their productivity (Ahmed et al., 2018).

\section{Service-Profit Chain}

A major aim in daily hotel practice is profitability, which is often taken as an indicator of organisational success, but such a universal and ideal as that is only representative of a generalization of other important organisational factors, which cause the attainment of that goal (which would not be possible in their absence). One of those important influencing factors is employee satisfaction. Heskett and Schlesinger, (1994) suggested their service profit chain, which explains that profit and growth are stimulated, mainly by customer loyalty resulting from customer satisfaction. Also, satisfaction is affected by the value of services, created by satisfied, loyal and productive employees.

Diverse scientific literature and practical examples show the importance of employee satisfaction and its causal connection to job performance (Brayfield \& Crockett, 1955; Judge et al., 2001; Naylor et al., 2013; Testa et al., 1998). This relationship has been described as "Holy Grail" of industrial psychologists (Landy, 1989). Although there is a significant amount of research where employee satisfaction has been examined by means of numerous motivational factors, the research is lacking in studies which focused on Service-Profit Chain Theory to explain the factors that could lead to increase or decrease in job satisfaction for hotel employees, which in turn, will affect job performance.

Therefore, SPC able to shape the current study's theoretical ground with consideration on the direct and significant connection between job satisfaction and job performance in order to achieve customer satisfaction and further increase the profitability particularly in hotel sector. This was illustrated in the theoretical framework prosed by Kelloway \& Myers, (2019)

\section{Model}

This study addresses all three elements of an organisational structure, tow elements of leadership style with respect to the way they impact job satisfaction and job performance. The framework was built based on the transformational, transactional, resource-based view and social exchange theories, transformational leadership theory, and Service profit chain theories. 


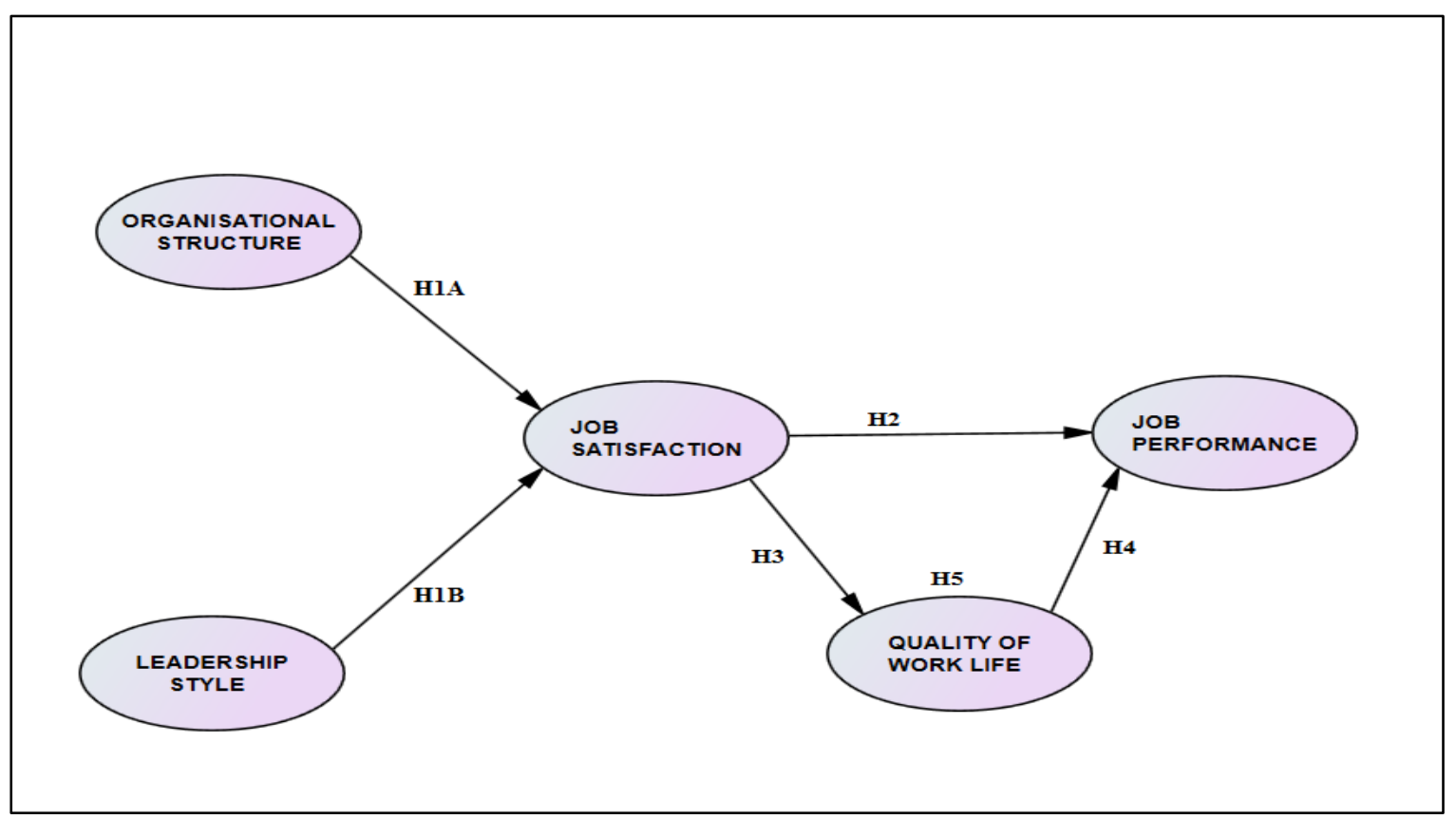

Figure 1: Theoretical Model

\section{Methodology}

The study has been conducted in Amman and Aqaba, Jordan with the aim to examine the influence the of job satisfaction antecedents on job performance, with quality of work life as mediating in 5 star rated hotels. The study used the quantitative approach and used the structured questionnaire as the research instrument. The target population of this study is the employees working in operational departments such as food and beverage department, housekeeping department and front office department. The sample size is 460 for this study as per $\mathrm{G}$ power analysis. The respondents were chosen by using purposive sampling technique. A drop-off and pick-up method were used to collect data. A total of 430 questionnaires were distributed and the usable questionnaires from the survey, yielding response rate of 95.86 percent. The study used a ten-point Likert scale in the survey instrument, which ranging from strongly disagree (1) to strongly agree (10). The measurement items of variables adapted as presented in Table 2, 3, 4, 5 and Table 6 respectively.

\section{Table 2: Adapted Questionnaire for Job Performance}

No. Adapted items

1. My work efficiency is much higher than average.

2. My standards of work quality are higher than the formal standards for this job.

3. My work meets expectations of my manager.

4. I strive for higher quality work than required.

5. I expect to be promoted faster than average.

6. I am far more knowledgeable than others who work in my area of expertise.

7. I find real enjoyment in my job, and I am fairly well satisfied.

8. I like my job better than the average worker.

9. I intend to remain in my profession.
Retained/dropped

Retained

Retained

Retained

Retained

Dropped

Dropped

Dropped

Dropped

Dropped

Source: Naser \& Shokouh, 2016 
Table 3: Adapted Questionnaire for Quality of Work Life

No. Adapted items

Retained

/dropped

1. I do my best to stay healthy and fit.

Retained

2. I am satisfied with what I'm getting paid for my work.

Retained

3. I feel that my business is secure.

Retained

4. My business does well for my family.

Retained

5. My place of work is collegial.

Retained

6. I have enough time away from work to enjoy other thing in life.

Retained

7. I feel appreciated at work.

Retained

8. People at work and/or within my profession respect me as

Achieved professional and expert.

9. I feel that my work allows me to realize my full potential.

Dropped

10. I feel that I am releasing my potential as an expert in my line of

Dropped work.

11. I feel that I'm always learning new things that help to do my job

Dropped better.

12. My work allows me to developed my professional skills.

Dropped

13. My work helps me to developed my creativity outside of work.

Dropped

Source: Lan et al., 2015

Table 4: Adapted Questionnaire for Job Satisfaction

\begin{tabular}{llc}
\hline No. & Adapted items & Retained /dropped \\
\hline 1. & I am willing to work harder to help this company succeed. & Retained \\
2. & I am proud to work for this hotel. & Retained \\
3. & I feel a strong sense of belonging to this organization. & Retained \\
4. & I would refer a friend to come work at hotel. & Retained \\
5. & Overall, I am satisfied working at this hotel. & Retained \\
\hline
\end{tabular}

Source: Hassi, 2018

Table 5: Adapted Questionnaire for Leadership Style

\begin{tabular}{llc}
\hline No. & Adapted items & $\begin{array}{c}\text { Retained } \\
\text { /dropped }\end{array}$ \\
\hline 1. & $\begin{array}{l}\text { My Managers specify who is responsible for performance } \\
\text { target. }\end{array}$ & Retained \\
2. & $\begin{array}{l}\text { My Managers clarify rewards. } \\
\text { 3. }\end{array} \quad \begin{array}{l}\text { I tend to motivate my followers to seek different perspective } \\
\text { when solving problems. }\end{array}$ & Retained \\
4. & $\begin{array}{l}\text { I often find out what my employees want and try to help } \\
\text { them get it. }\end{array}$ & Retained \\
5. & $\begin{array}{l}\text { My Managers draw attention toward failure in order to meet } \\
\text { standards. }\end{array}$ & Retained \\
&
\end{tabular}

Source: Sanda \& Dodua, 2017 
Table 6: Adapted Questionnaire for Organisational Structure

\begin{tabular}{lll}
\hline No. & Adapted items & $\begin{array}{c}\text { Retained } \\
\text { /dropped }\end{array}$ \\
\hline 1. & My company encourage knowledge sharing among employees. & Retained \\
2. & $\begin{array}{l}\text { My company has possessed in place to facilitates knowledge } \\
\text { exchange and conversion across business function. }\end{array}$ & Retained \\
3. & $\begin{array}{l}\text { My company structure promotes collaborative rather than } \\
\text { individualistic working behaviour. }\end{array}$ & Retained \\
4. $\quad \begin{array}{l}\text { My company structure facilities knowledge discovery and creation. } \\
\text { 5. }\end{array} \quad \begin{array}{l}\text { My company possesses the system to collect various successful and } \\
\text { failed experience. }\end{array}$ & Retained \\
6. My company has a high "reuse rate" of important knowledge. & Dropped \\
7. My company has common knowledge platform to enable & Dropped \\
\hline
\end{tabular}

Source: valaei, 2017

\section{Assessment of Measurement Model}

The measurement model is examined for the internal consistency reliability, convergent validity, and discriminant validity. Consistency reliability of the constructs is examining through the Cronbach's alpha, composite reliability (Hair, Hult, Ringle \& Sarstedt, 2017; Dijkstra \& Henseler, 2015b). Moreover, convergent validity of the constructs is examined through the outer loadings, and average variance extracted (AVE) (Hair et al., 2017; Hair, Hult, Ringle \& Sarstedt, 2014). On the other hand, discriminant validity of the constructs is examined using cross-loadings, Forner-Lacker criterion as suggested by Hair et al., (2017) and Henseler, Ringle \& Sarstedt, (2015). The threshold value is 0.70 for Cronbach's alpha, composite reliability that indicates internal consistency (Ramayah, Cheah, Chuah, Ting \& Memon, 2018). All the constructs involved in this study exceeded the threshold criterion. For outer loadings, the threshold value is 0.70 and for AVE, the threshold value is 0.50 , which suggested an adequate convergent validity (Hair et al., 2017; Hair, Black, Babin, Anderson, \& Tatham, 2010; Bagozzi \& Yi, 1988; Byrne, 2016). All the constructs involved in this study were exceeded the threshold criterion. Table 7 shows the Cronbach's alpha, composite reliability and average variance extracted (AVE) for all the constructs.

Table 7: Validity and Reliability Test of The Measurement Model

\begin{tabular}{lccc}
\hline \multicolumn{1}{c}{ Construct } & $\begin{array}{c}\text { FACTOR } \\
\text { LOADING }\end{array}$ & $\begin{array}{c}\text { AVE } \\
\text { (MINIMUM } \\
\mathbf{0 . 5}\end{array}$ & $\begin{array}{c}\text { CR } \\
\text { (MINIMUM } \\
\mathbf{0 . 7})\end{array}$ \\
\hline $\begin{array}{l}\text { Job performance (JP) } \\
\text { My work efficiency is much higher than } \\
\text { average. (JP1) }\end{array}$ & 0.878 & $\mathbf{0 . 7 6 1}$ & $\mathbf{0 . 9 0 5}$ \\
$\begin{array}{l}\text { My standards of work quality are higher } \\
\text { than the formal standards for this job. (JP2) }\end{array}$ & 0.947 & & \\
$\begin{array}{l}\text { I strive for higher quality work than } \\
\text { required. (JP4) }\end{array}$ & 0.784 & \\
$\begin{array}{l}\text { Job satisfaction (JS) } \\
\text { I am proud to work for this hotel. (JS2) }\end{array}$ & & & \\
I feel a strong sense of belonging to this \\
organization. (JS3)
\end{tabular}




\begin{tabular}{|c|c|c|c|}
\hline $\begin{array}{l}\text { Overall, i am satisfied working at this hotel. } \\
\text { (JS5) }\end{array}$ & 0.869 & & \\
\hline Leadership style (LS) & & 0.805 & 0.943 \\
\hline $\begin{array}{l}\text { I tend to motivate my followers to seek } \\
\text { different perspective when solving } \\
\text { problems. (LS1) }\end{array}$ & 0.944 & & \\
\hline $\begin{array}{l}\text { I often find out what my employees want } \\
\text { and try to help them get it. (LS2) }\end{array}$ & 0.930 & & \\
\hline $\begin{array}{l}\text { My managers specify who is responsible for } \\
\text { performance target. (LS3) }\end{array}$ & 0.834 & & \\
\hline My managers clarify rewards. (LS4) & 0.877 & & \\
\hline Organisational structure (OS) & & 0.652 & 0.918 \\
\hline $\begin{array}{l}\text { My company encourage knowledge sharing } \\
\text { among employees. (OS1) }\end{array}$ & 0.791 & & \\
\hline $\begin{array}{l}\text { My company structure promotes } \\
\text { collaborative rather than individualistic } \\
\text { working behavior. (OS2) }\end{array}$ & 0.895 & & \\
\hline $\begin{array}{l}\text { My company structure facilities knowledge } \\
\text { discovery and creation. (OS3) }\end{array}$ & 0.914 & & \\
\hline $\begin{array}{l}\text { My company possesses the system to collect } \\
\text { various successful and failed experience. } \\
\text { (OS4) }\end{array}$ & 0.918 & & \\
\hline $\begin{array}{l}\text { My company has a high "reuse rate" of } \\
\text { important knowledge. (OS5) }\end{array}$ & 0.883 & & \\
\hline Quality of work life (QWL) & & 0.730 & 0.940 \\
\hline I do my best to stay healthy and fit. (QWL1) & 0.850 & & \\
\hline $\begin{array}{l}\text { I am satisfied with what i'm getting paid for } \\
\text { my work. (QWL2) }\end{array}$ & 0.883 & & \\
\hline $\begin{array}{l}\text { My business does well for my family. } \\
\text { (QWL4) }\end{array}$ & 0.848 & & \\
\hline My place of work is collegial. (QWL5) & 0.841 & & \\
\hline $\begin{array}{l}\text { I have enough time away from work to } \\
\text { enjoy other thing in life. (QWL6) }\end{array}$ & 0.875 & & \\
\hline I feel appreciated at work. (QWL7) & 0.811 & & \\
\hline
\end{tabular}

The Fornell-Larcker criterion, where the square root of AVE (diagonal) is larger than its correlations (off-diagonal) for all constructs. Table 8 shows that the square root of AVE of each of the constructs is larger than its correlations with other constructs. 
Table 8: Discriminant Validity -Fornell Lacker

\begin{tabular}{|c|c|c|c|c|c|}
\hline CONSTRUCT & $\begin{array}{c}\text { Job } \\
\text { performance }\end{array}$ & $\begin{array}{c}\text { Job } \\
\text { satisfaction }\end{array}$ & $\begin{array}{c}\text { Leadership } \\
\text { style }\end{array}$ & $\begin{array}{l}\text { Organizatio } \\
\text { n structure }\end{array}$ & $\begin{array}{c}\text { Quality } \\
\text { of work } \\
\text { life }\end{array}$ \\
\hline Job performance & 0.87 & & & & \\
\hline Job satisfaction & 0.67 & 0.84 & & & \\
\hline Leadership style & 0.50 & 0.54 & 0.90 & & \\
\hline $\begin{array}{l}\text { Organization } \\
\text { structure }\end{array}$ & 0.69 & 0.60 & 0.48 & 0.81 & \\
\hline $\begin{array}{l}\text { Quality of work } \\
\text { life }\end{array}$ & 0.78 & 0.80 & 0.66 & 0.69 & 0.85 \\
\hline
\end{tabular}

\section{The Coefficient of Determination, R2}

According to Chin, (1998) stated that 0.67, 033, 019 respectively, describing substantial, moderate, or weak levels of predictive accuracy. Table 9 shows the R2 values, which is 0.62 , implying that $62 \%$ of job performance is predicted by job satisfaction and quality of work life.

Construct

Job Performance
Table 9: $\mathbf{R}^{2}$ values

$R^{2}$

0.62

Next, the assessment of the structural model for examining the hypothesized relationships among the constructs through a bootstrapping procedure with 5000 sub samples (Hair et al., 2017). The path coefficients are obtained for the structural model relationships, which represent the hypothesized relationships that link the constructs by looking at the beta $(\beta), \mathrm{R} 2$, and the corresponding t-values (Hair et al., 2017; Hair, Ringle \& Sarstedt, 2011). Table 10 shows the significance results of the structural model. All the hypothesized relationships are supported at $\mathrm{p}<0.01$.

Table 10: The Regression Path Coefficient and Its Significance Based on p-value $<0.05$

\begin{tabular}{|c|c|c|c|c|c|c|c|}
\hline \multicolumn{3}{|c|}{ Structural Relationship } & \multirow{2}{*}{$\begin{array}{c}\text { Estimate } \\
\text { (Actual } \\
\text { Beta) }\end{array}$} & \multirow{2}{*}{$\begin{array}{l}\text { S.E. } \\
0.054\end{array}$} & \multirow{2}{*}{$\begin{array}{l}\text { C.R. } \\
9.704\end{array}$} & \multirow{2}{*}{$\begin{array}{c}\text { P-value } \\
* * *\end{array}$} & \multirow{2}{*}{$\begin{array}{l}\text { Result } \\
\text { Significant }\end{array}$} \\
\hline JS & $<---$ & OS & & & & & \\
\hline JS & $<---$ & $\mathrm{LS}$ & 0.25 & 0.032 & 7.786 & $* * *$ & Significant \\
\hline QWL & $<---$ & JS & 0.84 & 0.048 & 17.708 & $* * *$ & Significant \\
\hline $\mathrm{JP}$ & $<---$ & JS & 0.23 & 0.079 & 2.994 & $* * *$ & Significant \\
\hline JP & $<---$ & QWL & 0.62 & 0.081 & 7.697 & $* * *$ & Significant \\
\hline
\end{tabular}

\section{Finding}

In line with the preceding studies, it was revealed that there is a positive interconnection between the proposed factors; therefore, based on the literature, it is clear that organisational structure, leadership style and quality of work life are linked to the job performance. In the present study, job satisfaction not only influences the quality of work life, but it also was influenced by organisational structure and leadership style. Besides that, quality of work life not only linked to job performance but also act as a mediator on the relationship between job satisfaction and job performance. In this way, it is imperative for Jordanian hotels to put 
resources into various activities to advance job satisfaction with a specific goal to enhance job performance (Shanmugam \& Ganapathy, 2017; Malik et al., 2017; Masa'deh, 2016; Chanana \& Gupta, 2016; Salimbahrami et al., 2015; Yadav \& Khanna, 2014; Avolio et al., 2009; AlAbabneh, 2013; Zhao et al., 2011).

The outcomes obtained were in line with those acquired in the preceding studies that demonstrated organisation structure, leadership style, job satisfaction, quality of work life to influence job performance (Aketch et al., 2012; Chanana \& Gupta, 2016; Al-Laymoun, 2017; Shabbir, 2017). As the study by Wanjala (2014), a larger part of the organisation success and effectiveness (special in the hotel industry) depend on employee's satisfaction and performance.

\section{Conclusion}

This study primarily attempted to examine the relationship between organisation structure, leadership style, job satisfaction, quality of work life, and job performance and intention to use job performance on the basis of the relevant studies in the context of the hotel industry. In today's competitive world, the key to success in any business, such as the hotel industry, relies on the employees who are the assets of any organisation and who play a crucial role in driving the profit of an organisation. Thus, organisations have to be concerned about their employees' job satisfaction and quality of work life. The present study proposes a conceptual framework of the relationship between organisation structure, leadership style, job satisfaction, quality of work life, and job performance for the enhancement of knowledge, particularly in the hotel industry.

\section{References}

Ahmed, A., Khuwaja, F. M., Brohi, N. A., Othman, I., \& Bin, L. (2018). Organizational factors and organizational performance: A resource-based view and social exchange theory viewpoint. International Journal of Academic Research in Business and Social Sciences, 8(3), 579-599.

Aketch, J. R., Odera, O., Chepkuto, P., \& Okaka, O. (2012). Effects of quality of work life on job performance: theoretical perspectives and literature review. Current Research Journal of Social Sciences, 4(5), 383-388.

Al-Ababneh, M. (2013). Leadership style of managers in five-star hotels and its relationship with employee's job satisfaction. Journal of Occupational and Organisational Psychology, 3(2), 94.

Al-Laymoun, M. R. (2017). THE ROLE OF THE TRANSFORMATIONAL LEADERSHIP IN UPGRADING THE PERFORMANCE OF THE FIVE STARS HOTELS STAFF FROM THE PERSPECTIVE OF HR MANAGERS. International Journal of Information, Business and Management, 9(4), 11.

Al-Refaie, A. (2015). Effects of human resource management on hotel performance using structural equation modeling. Computers in Human Behavior, 43, 293-303.

Avolio, B. J., Walumbwa, F. O., \& Weber, T. J. (2009). Leadership: Current theories, research, and future directions. Annual review of psychology, 60, 421-449.

Babu, H. R., \& Ramesh, M. (2013). Relationship between job satisfaction and quality of work life of employees in service sector. Perspectives of Innovations, Economics and Business, 13(2), 58-72.

Barbuto Jr, J. E. (2005). Motivation and transactional, charismatic, and transformational leadership: A test of antecedents. Journal of Leadership \& Organisational Studies, 11(4), 26-40. 
Barney, J. (1991). Firm resources and sustained competitive advantage. Journal of management, 17(1), 99-120.

Barney, J. B. (1986). Organisational culture: can it be a source of sustained competitive advantage? Academy of Management Review, 11(3), 656-665.

Bass, B. \&Riggio. RE (2006). Transformational Leadership: New Jersey: Lawrence Erlbaum Associates.

Bhavani, M., \& Jegadeeshwaran, M. (2014). Job Satisfaction and Quality of Work Life-A Case Study of Women Teachers in Higher Education. SDMIMD Journal of Management, $5(2), 1-12$.

Boisvert, M. P. (1977). The quality of working life: an analysis. Human relations, 30(2), 155160.

Brayfield, A. H., \& Crockett, W. H. (1955). Employee attitudes and employee performance. Psychological bulletin, 52(5), 396.

Brymer, E., \& Gray, T. (2006). Effective leadership: Transformational or transactional? Journal of Outdoor and Environmental Education, 10(2), 13.

Campbell, J., McCloy, R., Oppler, S., \& Sager, C. (1993). A theory of performance: In N. Schmitt \& WC Borman (Eds.), Personnel Selection in Organisations (pp. 35-70): San Francisco: Jossey-Bass.

Carayon, P. (1997). Temporal issues of Quality Working Life and Stress in Human-Computer Interaction. International Journal of Human-Computer Interaction, 9(4), 325-342.

Chanana, M., \& Gupta, S. K. (2016b). Quality of Work Life and Its Impact on Job Performance: A Study of S.B.I \& HDFC Banking Professionals. International Research Journal of Management, IT and Social Sciences, 3(5), 25-37.

Chen, M.-C., Huang, Y.-W., Hou, W.-L., Sun, C.-A., Chou, Y.-C., Chu, S.-F., \& Yang, T. (2015). The Correlations between Work Stress, Job Satisfaction and Quality of Life among Nurse Anesthetists Working in Medical Centers in Southern Taiwan.

Chiang, F. F., Birtch, T. A., \& Cai, Z. (2014). Front-line service employees' job satisfaction in the hospitality industry: The influence of job demand variability and the moderating roles of job content and job context factors. Cornell Hospitality Quarterly, 55(4), 398407.

Cole, M. S., Schaninger Jr, W. S., \& Harris, S. G. (2002). The workplace social exchange network: A multilevel, conceptual examination. Group \& Organisation Management, 27(1), 142-167.

Council, W. T. a. T. (2017). Travel and tourism economic impact 2017 Jordan. Retrieved from Retrieved from https://www.wttc.org/-/media/files/reports/economic-impactresearch/countries-2017/jordan2017.pdf

Damayanthi, H., Wichaikhum, O., \& Chontawan, R. (2014). Predicting factors of job satisfaction among nurses in Sri Lanka. International Journal of Pharmacy \& Biosciences, 1(1).

Eliyana, A., \& Ma'arif, S. (2019). Job satisfaction and organizational commitment effect in the transformational leadership towards employee performance. European Research on Management and Business Economics, 25(3), 144-150.

Gok, Ö. A., Akgunduz, Y., \& Alkan, C. (2017). The Effects of Job Stress and Perceived Organisational Support on Turnover Intentions of Hotel Employees. Journal of Tourismology, 3(2), 23-32.

Grant, A. M., \& Parker, S. K. (2009). 7 redesigning work design theories: the rise of relational and proactive perspectives. Academy of Management annals, 3(1), 317-375.

Hair, J. F., Ringle, C. M., \& Sarstedt, M. (2011). PLS-SEM: Indeed, a Silver Bullet. Journal of Marketing Theory and Practice, 19(2), 139-152. doi:10.2753/mtp1069-6679190202 
Hair, Jr, J. F., Babin, B. J., \& Krey, N. (2017). Covariance-Based Structural Equation Modeling in the Journal of Advertising: Review and Recommendations. Journal of Advertising, 46(1), 163-177.

Hamideh, S., Hossein, A., Fatemeh, Z. H., Hassan, M., Kobra, A., \& Hassan, M. S. (2015). The Relation of Organisational Structure and its Dimensions with Staff's Quality of Work Life. American International Journal of Contemporary Research, 5(3), 106-114.

Heskett, J. L., \& Schlesinger, L. A. (1994). Putting the service-profit chain to work. Harvard business review, 72(2), 164-174.

Hofmann, V., \& Stokburger-Sauer, N. E. (2017). The impact of emotional labor on employees' work-life balance perception and commitment: A study in the hospitality industry. International Journal of Hospitality Management, 65, 47-58.

Hosmani, A., \& Shambhushankar, B. (2014). Study on Impact of Quality of Work Life on Job Performance amongst Employees of Secunderabad Division of South-Central Railway. Research Journal of Managemnet Sciences, 3(11), 8-11.

Judge, T. A., Thoresen, C. J., Bono, J. E., \& Patton, G. K. (2001). The job satisfaction-job performance relationship: A qualitative and quantitative review: American Psychological Association.

Kelloway, E. K., \& Myers, V. (2019). Leading the service-profit chain: how leaders' behaviors can affect customer experience. Examining the Role of Well-being in the Marketing Discipline (Research in Occupational Stress and Well Being, Vol. 17), Emerald Publishing Limited, 71-90.

Khasawneh, M. S. (2016). An Empirical Study for Work Stresses in Jordanian Tourism Companies. International Business Research, 9(11), 169.

Kieu, H. Q. (2010). Leadership styles and organisational performance: A predictive analysis: University of Phoenix.

Kuo, H. T., Lin, K. C., \& Li, I. c. (2014). The mediating effects of job satisfaction on turnover intention for long-term care nurses in Taiwan. Journal of nursing management, 22(2), 225-233.

Landy, F. J. (1989). Psychology of work behavior: Thomson Brooks/Cole Publishing Co.

Lee, C. C., \& Grover, V. (1999). Exploring mediation between environmental and structural attributes: The penetration of communication technologies in manufacturing organisations. Journal of Management Information Systems, 16(3), 187-217.

Liu, B., Liu, J., \& Hu, J. (2010). Person-organisation fit, job satisfaction, and turnover intention: An empirical study in the Chinese public sector. Social Behavior and Personality: an international journal, 38(5), 615-625.

Malik, W. U., Javed, M., \& Hassan, S. T. (2017). Influence of Transformational Leadership Components on Job Satisfaction and Organisational Commitment. Pakistan Journal of Commerce \& Social Sciences, 11(1).

Masa'deh, R. e. (2016). The Role of Knowledge Management Infrastructure in Enhancing Job Satisfaction at Aqaba Five Star Hotels in Jordan.

Mowday, R. T., Porter, L. W., \& Steers, R. M. (2013). Employee_organisation linkages: The psychology of commitment, absenteeism, and turnover: Academic press.

Nabwire, M. (2014). Factors Affecting Implementation of Strategy A Case of Barclays Bank of Kenya. United States International University-Africa.

Naylor, J. C., Pritchard, R. D., \& Ilgen, D. R. (2013). A theory of behavior in organisations: Academic Press.

Northouse, P. G. (2017). Introduction to leadership: Concepts and practice: Sage Publications.

Øgaard, T., Marnburg, E., \& Larsen, S. (2008). Perceptions of organisational structure in the hospitality industry: Consequences for commitment, job satisfaction and perceived performance. Tourism Management, 29(4), 661-671. 
O'Neill, M. (2001). Measuring service quality and customer satisfaction.

Owolabi, A. B. (2015). Effect of Work-Family Conflict and Job Satisfaction on Quality of Work Life. Advances in Social Sciences Research Journal, 2(2).

Pan, F. C. (2015). Practical application of importance-performance analysis in determining critical job satisfaction factors of a tourist hotel. Tourism Management, 46, 84-91.

Picardi, C. (2017). Organisational Structure's Relationship to Job Satisfaction: Moderating Effects of Personality. Retrieved 2017, from UB ScholarWorks https://scholarworks.bridgeport.edu/xmlui/bitstream/handle/123456789/1836/340-

FacultyResearchDay2017_CarriePicardiPoster.pdf?sequence=1\&isAllowed=y

Practical Guide to Statistical Analysis. (2nd edition) Singapore: Pearson.

Rai, R., \& Tripathi, S. (2015). A Study on QWL and its effects on Job Performance. Journal of Management Scieces and Technology, 2(2), 33-42.

Ramayah, T., Cheah, J., Chuah, F., Ting, H., \& Memon, M. A. (2018). Partial Least Squares

Rumelt, R. P., \& Lamb, R. (1997). Towards a strategic theory of the firm. Resources, firms, and strategies: A reader in the resource-based perspective, 131-145.

Salimbahrami, S. H., Ahmadi, H., Hajikolaei, F. Z., Mirzajani, H., Asheghan, K., \& Sahebi, H. M. (2015). The Relation of Organisational Structure and its Dimensions with Staff's Quality of Work Life. American International Journal of Contemporary Research, 3(5), 106-114.

Sekaran, U., \& Bougie, R. (2010). Research Method for Business, A Skill Building Approach. : John Wiley \& Sons Inc. Singapore.

Shabbir, M. S. (2017). Organisational Structure and Employee's Performance: A Study of Brewing Firms in Nigeria. American Research Journal of Business and Management, $3(1), 16$.

Shanmugam, B., \& Dr. Ganapathy, R. ((2017)). A Study on Quality of Work Life and Job Performance of Construction Workers in Chennai. International Journal of Scientific Research and Modern Education, 2(1), 68-71.

Sinha, C. (2012). Factors affecting quality of work life: Empirical evidence from Indian organisations. Australian Journal of Business and Management Research, 1(11), 3140.

Srivastava, P. (2016). LEADERSHIP STYLES IN WESTERN \& EASTERN SOCIETIES AND ITS RELATION WITH ORGANISATIONAL PERFORMANCE. Pranjana: The Journal of Management Awareness, 19(1).

Structural Equation Modeling (PLS-SEM) Using SmartPLS 3.0: An Updated and

Taylor, J. (2007). The impact of public service motives on work outcomes in Australia: a comparative multi-dimensional analysis. Public administration, 85(4), 931-959.

Teece, D. J., Pisano, G., \& Shuen, A. (1997). Dynamic capabilities and strategic management. Strategic management journal, 509-533.

Testa, M. R., Skaruppa, C., \& Pietrzak, D. (1998). Linking job satisfaction and customer satisfaction in the cruise industry: implications for hospitality and travel organisations. Journal of Hospitality \& Tourism Research, 22(1), 4-14.

Thomas, O. O. (2015b). Effects of Organisational Structure on Job Satisfaction in the Nigerian Financial Sector: Empirical Insight from Selected Banks in Lagos State. NG-Journal of Social Development, 5(1), 96-108.

Tran, Q., \& Tian, Y. (2013). Organisational structure: Influencing factors and impact on a firm. American Journal of Industrial and Business Management, 3(2), 229.

Wanjala, M. (2014). The Influence of Leadership Style on Employees' Job Performance in the Hospitality Industry: Case Study of Safari Park Hotel. United States International University-Africa. 
Wernerfelt, B. (1984). A resource-based view of the firm. Strategic management journal, 5(2), 171-180.

Whitcomb, K. M., Önkal, D., Curley, S. P., \& George Benson, P. (1995). Probability judgment accuracy for general knowledge. Cross-national differences and assessment methods. Journal of Behavioral Decision Making, 8(1), 51-67.

Xerri, M. (2013). Workplace relationships and the innovative behaviour of nursing employees: a social exchange perspective. Asia Pacific Journal of Human Resources, 51(1), 103123.

Yadav, R., \& Khanna, A. (2014). Employees' Satisfaction on Quality of Worklife at State Bank of India.

Yalabik, Z. Y., Rayton, B. A., \& Rapti, A. (2017, December). Facets of job satisfaction and work engagement. In Evidence-based HRM: a global forum for empirical scholarship. Emerald Publishing Limited.

Zehir, C., Ertosun, Ö. G., Zehir, S., \& Müceldili, B. (2011). The effects of leadership styles and organisational culture over firm performance: Multi-National companies in İstanbul. Procedia-Social and Behavioral Sciences, 24, 1460-1474.

Zhao., X. R., Qu, H., \& Ghiselli, R. (2011). Examining the relationship of work-family conflict to job and ife satisfaction: A case of hotel sales managers. International Journal of Hospitality Management, 46-54.

Zheng, W., Yang, B., \& McLean, G. N. (2010). Linking organizational culture, structure, strategy, and organizational effectiveness: Mediating role of knowledge management. Journal of Business research, 63(7), 763-771. 